\title{
LAYOUT OF COMPUTER CLASSROOM - COMPARISON AND ANALYSIS OF POSSIBLE SOLUTIONS
}

\section{Jiří DOSTÁL - Zuzana KOPEČKOVÁ}

\begin{abstract}
This paper compares possible solutions of layout of computer classrooms. It analyzes the conditions to the needs of the educational process. Particular attention is given to the student and teacher as objects of research.

Key words: ergonomics, computer lab, research, teacher, student.

\section{DISPOZIČNÍ USPOŘÁDÁNÍ POČÍTAČOVÉ UČEBNY - KOMPARACE A ANYLÝZA MOŽNÝCH ŘEŠENÍ}

Resumé: Článek na základě realizovaného výzkumného šetření komparuje možná řešení dispozičního uspořádání počítačových učeben. Jsou analyzovány podmínky z hlediska potřeb edukačního procesu. Zvláštní zřetel je brán na žáka a učitele jako objekty zkoumání.

Klićová slova: ergonomie, počítačová učebna, výzkum, učitel, žák.

\section{1 Úvod}

Každá základní či střední škola dnes disponuje počítačovou učebnou, kde probíhá výuka počítačově orientovaných předmětů nebo i předmětů jiného zaměření, avšak s počítačovou podporou. S počítačovými učebnami se lze v ojedinělých prípadech setkat i v mateřských školkách, spíše zde však nalezneme počítačové koutky.

Počítačová učebna může mít různé dispoziční uspořádání, což do určité míry ovlivňuje i volbu a využívání vyučovacích metod a organizačních forem. Je-li např. učebna řešena tak, že jsou stoly $\mathrm{s}$ počítači uspořádány $\mathrm{v}$ řadě za sebou, je možné bez problémů využít monologické metody a frontální výuku, avšak skupinové vyučování, př̀i kterém by měli studenti řešit problémy ve čtyřčlenných skupinách již využít jednoduše nelze. Je ale možné realizovat kooperační výuku prostřednictvím počítačové sítě.

\section{Uspořádání stolů $s$ počítači $v$ řadě za sebou}

Tento typ uspořádání stolů (viz obr. 1.) vychází z nejrozšiřrenější a nejčastěji využívané organizační formy, kterou je frontální výuka. Je obdobný jako v běžných školních trrídách, kde žáci sedí $\mathrm{v}$ řadách za sebou čelem $\mathrm{k}$ tabuli. Toto řešení se uplatní zejména tam, kde jsou učebny dostatečně prostorné. Počitač učitele se nejčastěji umist'uje před žáky, poprrípadě za žáky, což je však ojedinělé řešení. Počet řad je omezen rozměrem učebny, dále se přizpůsobuje potřebám výuky, pro kterou je projektována. Při návrhu je nutné dodržovat minimální vzdálenost $1-1,5 \mathrm{~m}$ mezi studentem a zadním krytem monitoru umístěným za ním, jinak nastávají problémy s pohybem žáků i učitele.

Výhody:

- žáci vidí na tabuli, promítací plátno a učitele, aniž by se museli otáčet,

- do učebny Ize umístit více počítačů jedná se o velmi ekonomické řešení,

- $\quad$ v prrípadě, že je učitelský stůl s počítačem umístěn vzadu, má učitel snadný přehled o činnosti všech žáků.

Nevýhody:

- žáci vidí na monitory před sebou, což jim umožňuje výskyt nežádoucího chování (např. opisování),

- obtížnější pohyb učitele a př́stup $\mathrm{k}$ jednotlivým studentům,

- problematická montáž a zabezpečení kabelů (náročnější instalace),

- $\quad$ v prípadě, že je učitelský počítač umístěn v přední části učebny, nemá učitel přehled o činnosti žáků - to však Ize odstranit využíváním speciálního software. 


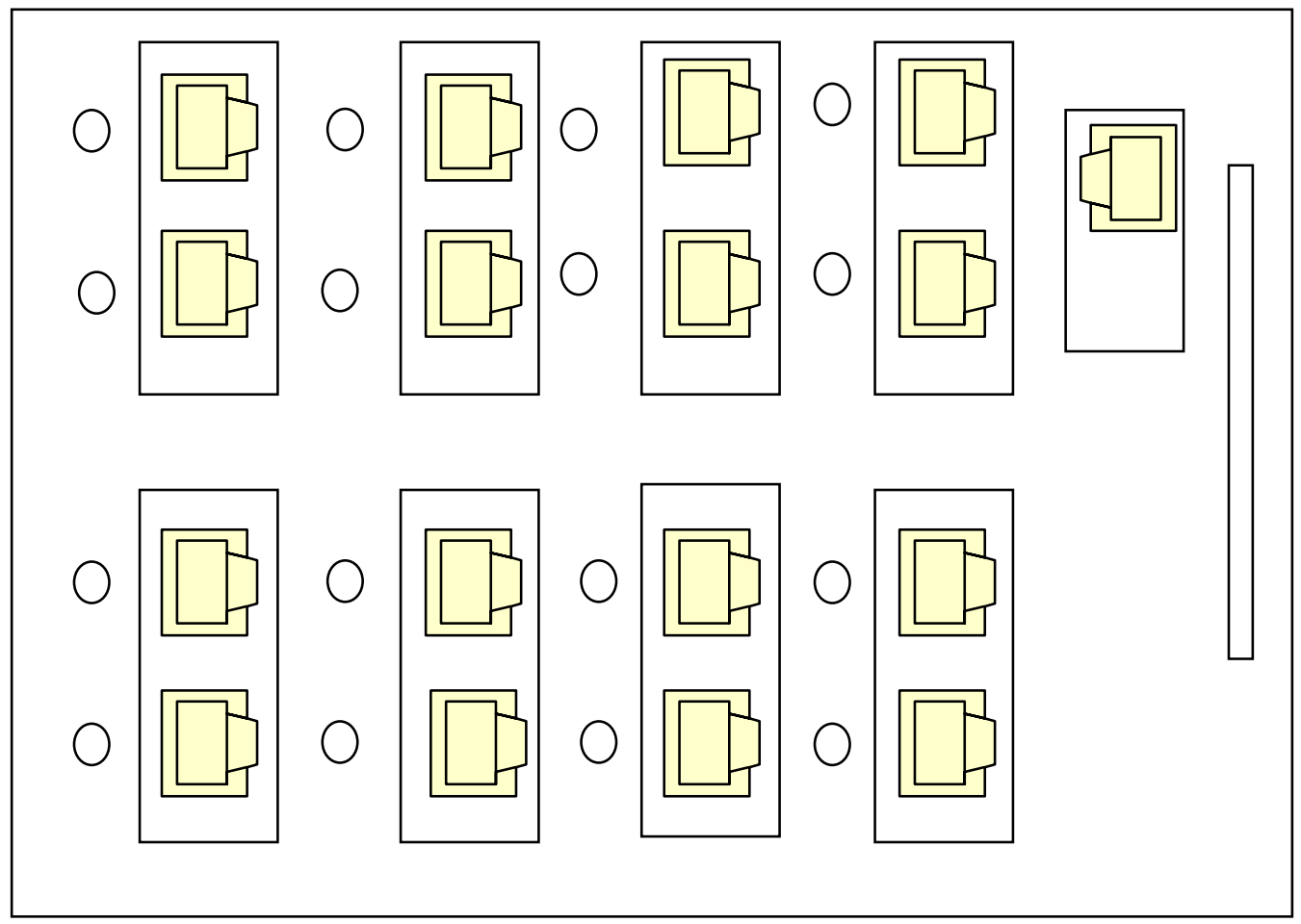

Obrázek 1: Uspořádání stolů s počítači v řadě za sebou

2 Uspořádání stolů $s$ počítači $v$ řadě kolmo $k$ tabuli

Méně tradičním dispozičním řešením učebny je uspořádání stolů $\mathrm{s}$ počítači $\mathrm{v}$ řadě kolmo $\mathrm{k}$ tabuli (viz obr. 2). Jde o takové uspořádání, kdy počítače jsou zadní stěnou monitoru $\mathrm{k}$ sobě. $\mathrm{V}$ čele učebny nebo $\mathrm{v}$ zadní části je umístěn učitelský počítač.

Výhody:

- využití v malých učebnách,

- do učebny lze umístit velký počet počítačů - jedná se o nejekonomičtější řešení,

- $\quad$ snadná instalace a zabezpečení kabeláže.
Nevýhody:

- $\quad$ studenti se musí natáčet $\mathrm{k}$ tabuli,

- učitel nevidí na všechny monitory,

- $\quad$ osvětlení monitorů v řadě u oken (hrozí osInění),

- $\quad$ žáci přes monitory na sebe vidí (možnost nežádoucí komunikace _ verbální i neverbální),

- obtížnost kontroly všech žáků najednou (vyučující vidí vždy jen jednu stranu). 


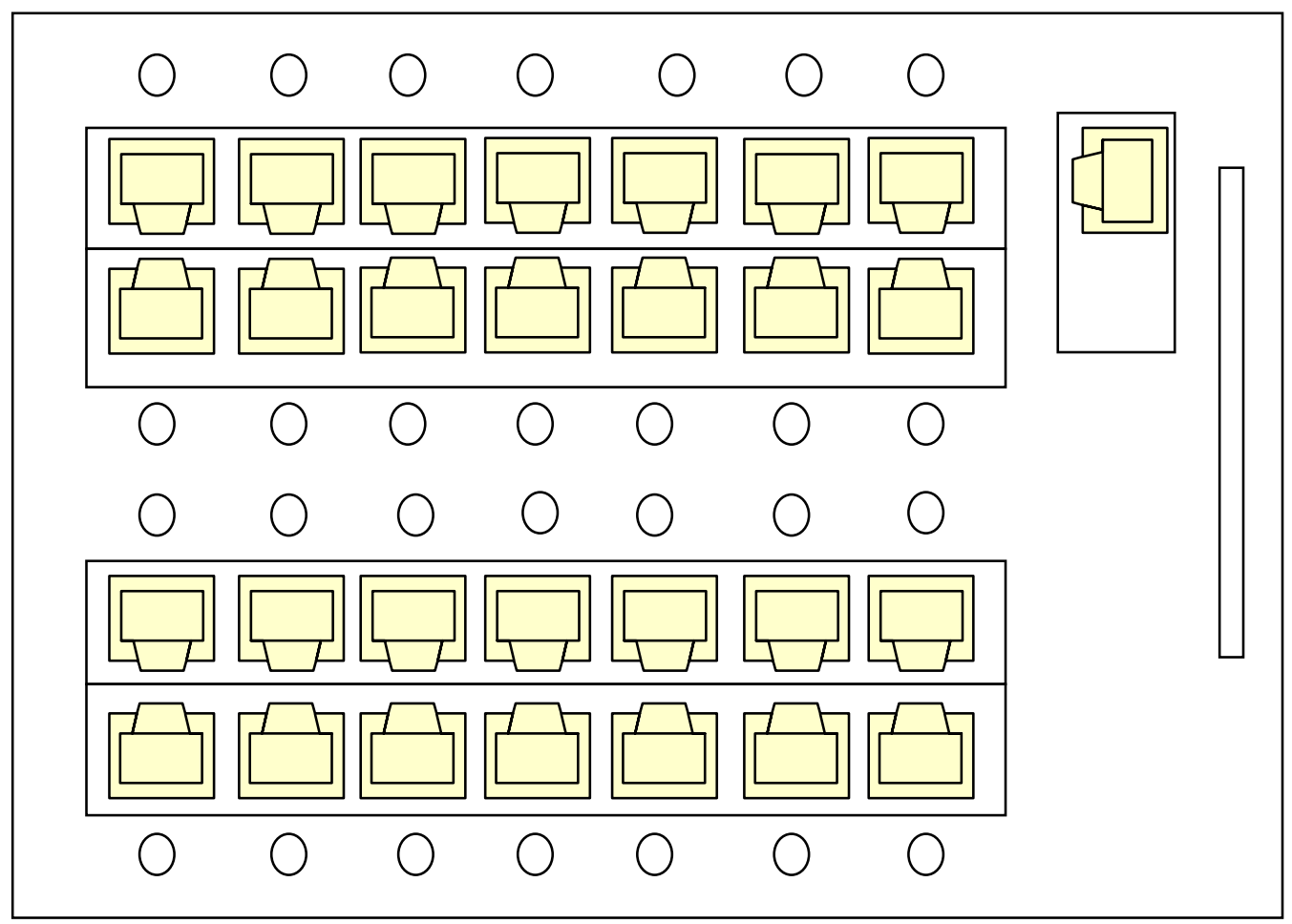

Obrázek 2: Uspořádání stolů s počítači kolmo k tabuli

3 Podkova u zdi (uspořádání po obvodě, žáci sedí uvnitřr)

$\mathrm{V}$ případě tohoto řešení počítačové učebny jsou jednotlivé počítačové stanice umístěny po obvodu tř́ zdí do tzv. podkovy a žáci sedí uvnitř (viz obr. 3). U čtvrté zdi je tabule a počítač učitele. Uprostřed učebny vznikne prázdné místo, kam lze popř́ípadě umístit dalši stoly s počítači.

Výhody:

- učitel má přehled o činnosti všech studentů a vidí na všechny monitory,

- $\quad$ snadný prístup ke studentům a pohyb mezi nimi,

- $\quad$ snadný pohyb pro studenty,

- $\quad$ snadná instalace a zabezpečení kabelů.

Nevýhody:

- žáci nevidí na tabuli a musí se otáčet,

- do učebny lze umístit méně počítačù,

- žáci v rozích mohou židlemi navzájem kolidovat.

4 Podkova uprostř̌ed učebny (uspořádání po obvodě, žáci sedí vně)

Obdobné uspořádání jako u podkovy u zdi. Počítače jsou také rozmístěny podél tří stěn do podkovy, studenti však sedí zády ke zdem (viz obr. 4). Prostor mezi počítačem a zdí měl mít minimální rozměr 1 - 1,5 m, aby byl umožněn dostatečný prostor pro průchod učitele a studentů. Opět vzniká uprostřed učebny prázdné místo, které je však menší, než u uspořádání podkovy u zdi. Lze ho ovšem využít k umístění dalších počítačových stanic.

Výhody:

- Z žáci vidí na učitele, pokud stojí uprostřed učebny,

- žáci vidí na tabuli,

- snadná instalace.

Nevýhody:

- učitel nevidí na monitory všech studentů,

- obtížnější a pomalejší pohyb mezi studenty,

- osvětlení monitorů v řadě u oken (hrozí osInění),

- $\quad$ žáci na sebe vidí a mohou mít tendenci nežádoucím způsobem komunikovat. 


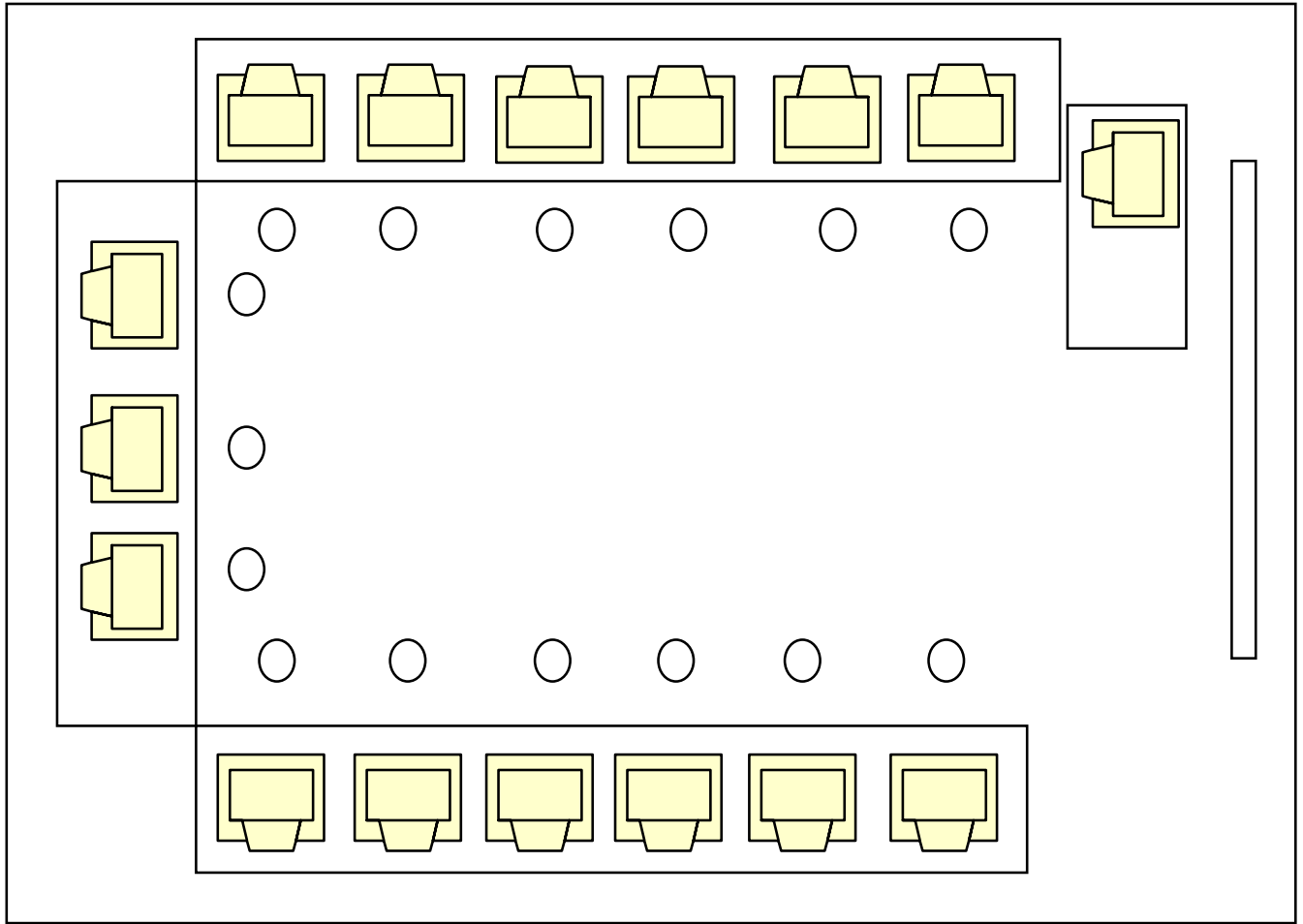

Obrázek 3: Podkova u zdi

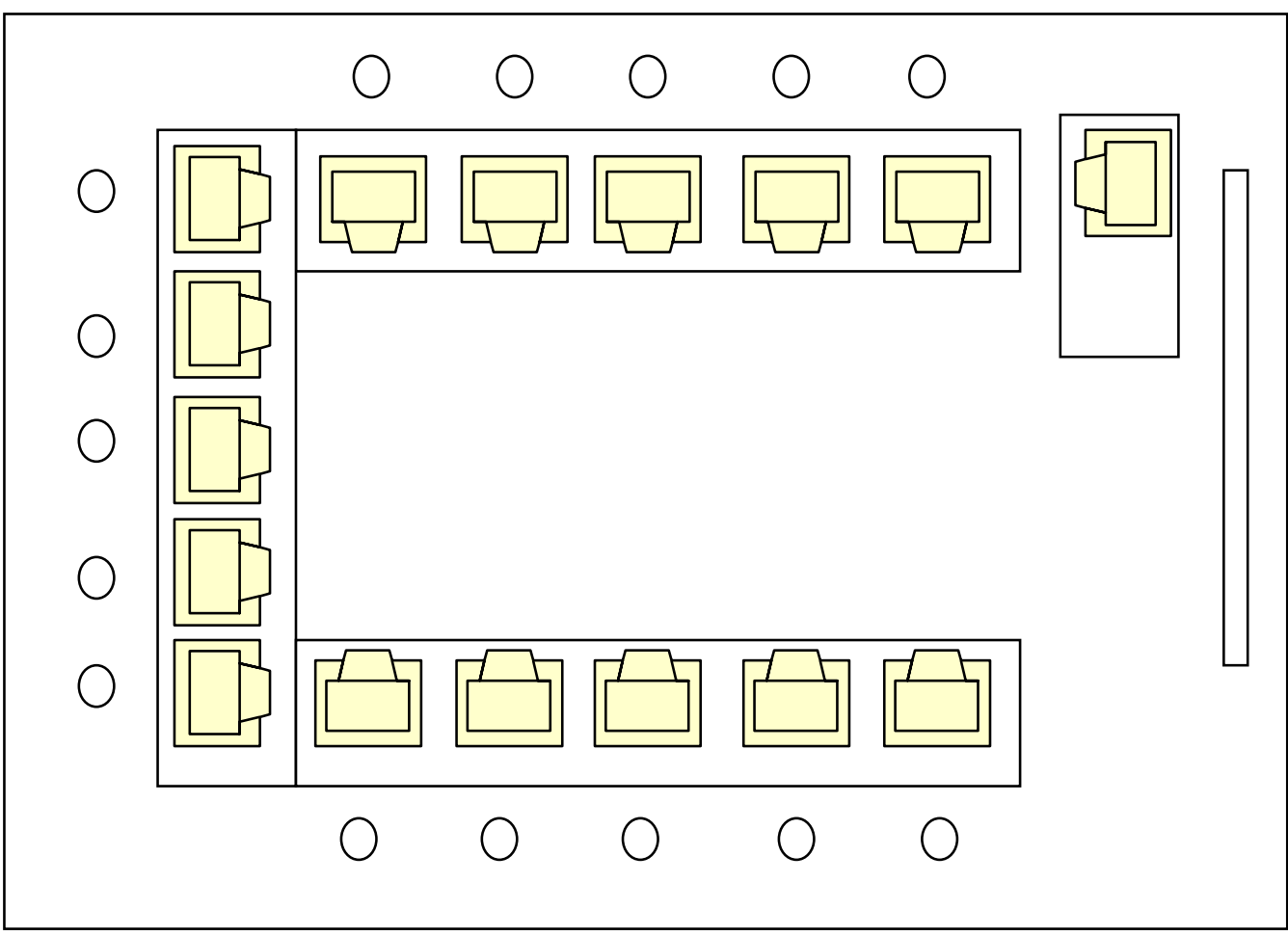

Obrázek 4: Podkova uprostřed učebny

\section{Výsledky výzkumného šetření}

Výzkumné šetření bylo realizováno formou dotazníku, který byl rozeslán na různé typy škol.
Vyplňoval ho vždy jeden $z$ vyučujících informaticky orientovaných předmětů na dané škole. Vrátilo se 85 řádně vyplněných dotazníků. 
Složení škol zapojených do výzkumu je zřetelné z následující tabulky.

Tabulka č. 1: struktura škol zapojených do výzkumu

\begin{tabular}{|c|c|c|c|c|c|c|}
\hline & \multicolumn{2}{|c|}{$\mathbf{Z S}$} & \multicolumn{2}{|c|}{ Š̃ } & \multicolumn{2}{|c|}{ VOŠ, Vঙ̌ } \\
\hline $\begin{array}{c}\text { Počet } \\
\text { respondentů }\end{array}$ & 34 & $\begin{array}{l}40,0 \\
\%\end{array}$ & 48 & $\begin{array}{l}56,5 \\
\%\end{array}$ & 3 & $3,5 \%$ \\
\hline
\end{tabular}

Typ uspořádání stolů $s$ počítači $v$ učebně

V rámci první dotazníkové položky nás zajímalo, jak jsou uspořádány stoly s počítači v učebně ve školách. Nabídka odpovědí na otázku obsahovala pět možností - v řadě za sebou, podkova u zdi, podkova uprostřed učebny, kolmo k tabuli a jiné. Dotazovaní mohli vybírat i více možností v př́ípadě, že na jejich škole je více učeben s různým typem uspořádání (někteří z dotazovaných této možnosti využili a označili více odpovědí).

Tabulka č. 2: Typ uspořádání stolů s počítači v učebně

\begin{tabular}{|l|l|c|}
\hline Uspořádání & \multicolumn{2}{|c|}{ Počet odpovědí } \\
\hline v řadě za sebou & 41 & $43,2 \%$ \\
\hline podkova u zdi & 33 & $34,7 \%$ \\
\hline podkova uprostřed učebny & 12 & $12,6 \%$ \\
\hline kolmo k tabuli & 9 & $9,5 \%$ \\
\hline jiné & 0 & $0 \%$ \\
\hline Celkem & $\mathbf{9 5}$ & $\mathbf{1 0 0 , 0}$ \\
\hline
\end{tabular}

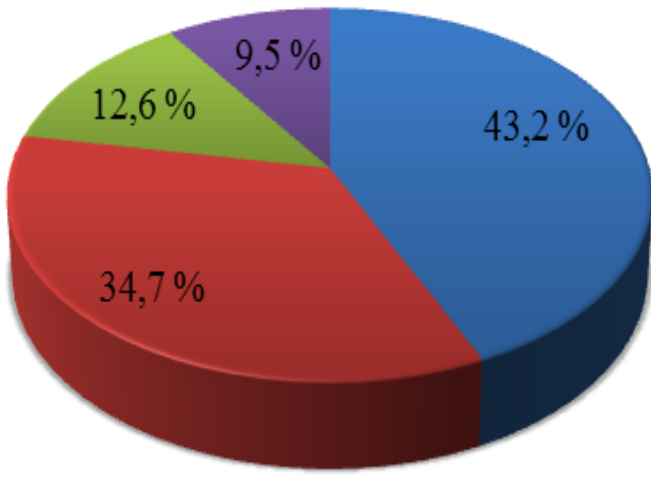

Gv řadě za sebou

•podkova u zdi

๑podkova uprostřed učebny

akolmo k tabuli

Graf č. 1: Typ uspořádání stolů s počítači v učebně

\footnotetext{
Spokojenost $\mathbf{s}$ uspořádáním stávající odpovědět ano, spíše ano, spíše ne a ne. učebny

Na dotazníkovou položku „Vyhovuje Vám $\mathrm{V}$ tabulce číslo 3 je uveden počet jednotlivých odpovědí a jejich procentuální vyjádření.
} toto uspořádání stávající učebny?“ bylo možné 
Tabulka č. 3: Spokojenost s uspořádáním stávající učebny

\begin{tabular}{|l|l|c|}
\hline Odpověd' & \multicolumn{2}{|c|}{ Počet odpovědí } \\
\hline ano & 47 & $55,3 \%$ \\
\hline spí̌̌e ano & 30 & $35,3 \%$ \\
\hline spíše ne & 7 & $8,2 \%$ \\
\hline ne & 1 & $1,2 \%$ \\
\hline Celkem & $\mathbf{8 5}$ & $\mathbf{1 0 0 , 0} \%$ \\
\hline
\end{tabular}

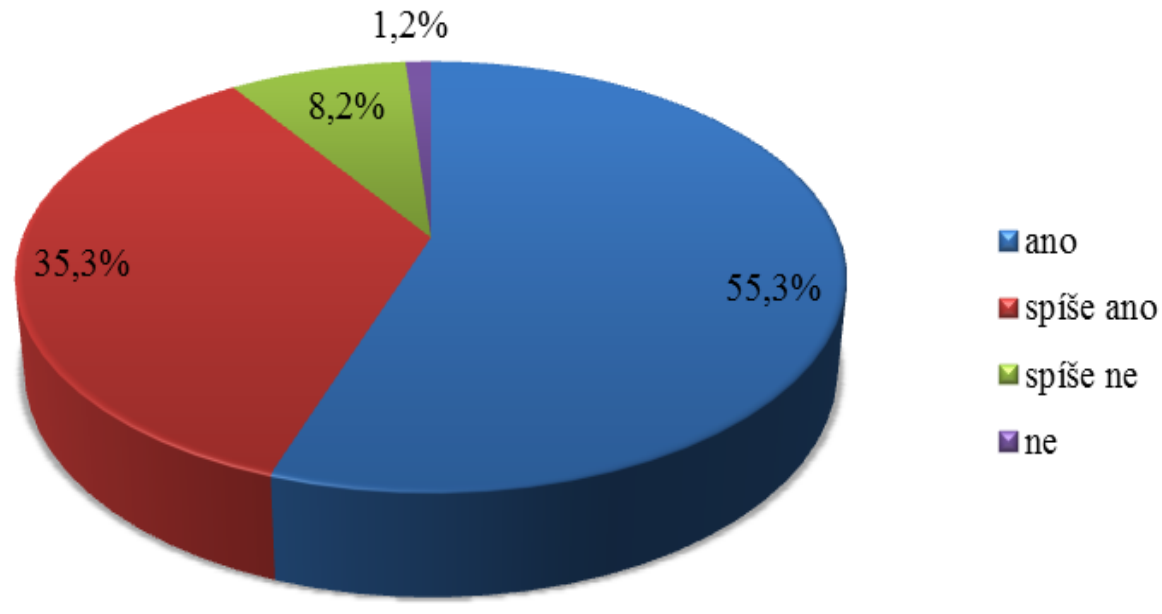

Graf č. 2: Spokojenost s uspořádáním stávající učebny

Počet studentů, kteří současně pracují na jednom počítači

Dále nás zajímalo, zda žáci pracují na počítači samostatně, nebo zda na jeden počítač připadá více studentů. Proto jsme do dotazníku zařadili otázku pro zjištění počtu studentů u jednoho počítače.

Tabulka č. 4: Počet studentů, kteří současně pracují na jednom počítači

\begin{tabular}{|c|c|c|c|c|c|}
\hline & \multicolumn{5}{|c|}{ Počet studentů } \\
\hline & & & & & více \\
\hline Počet respondentů & 69 & $81,2 \%$ & 16 & $18,8 \%$ & $0 \%$ \\
\hline
\end{tabular}

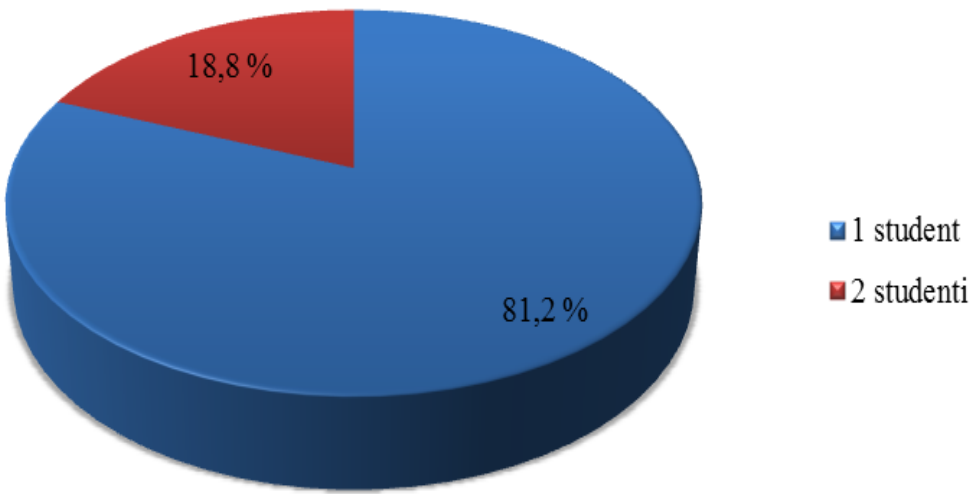

Graf č. 3: Počet studentů, kteří současně pracují na jednom počítači 


\section{Závěr}

V této studii zachycujeme a prezentujeme nejčastěji užívaná dispoziční řešení počítačových učeben na základních a středních školách v ČR. Výčet však není vyčerpávající. Prokázalo se, že neexistuje řešení, které by bylo zcela vyhovující - každé řešení má své výhody a nevýhody. $\mathrm{V}$ dalších výzkumech se budeme zaměřovat na souvislost využívání vyučovacích metod a organizačních forem ve vztahu k dispozičnímu uspořádání učebny. Zájemce o další informace odkazujeme na následně uvedené publikace (1-8).

\section{Literatura}

[1] KLEEN, B. A., SHELL, L. W., ZACHRY, B. Classroom Configuration And Instructional Technology Impact Teaching Methods. Review of Business Information Systems (RBIS). Vol 3, No 2 (1999). ISSN 1534-665X (print), ISSN 21579547 (online).

[2] GILBERTOVÁ, S., MATOUŠEK, O. Ergonomie: Optimalizace lidské činnosti. 1. vyd. Praha: Grada Publishing, 2002. 239 s. ISBN 80247-0226-6.

[3] NEŠPOR, K. Počitače a zdraví. 1. vyd. Praha: BEN, 1999. 96 s. ISBN 80-86056-71-6.

[4] Vyhláška 343/2009 Sb., O hygienických požadavcích na prostory a provoz zařizeni aprovozoven pro výchovu a vzdéláváni dospělých.

[5] CHUNDELA, L. Ergonomie. Praha: ČVUT, 2001. 171 s. ISBN 80-01-02301-X.

[6] MATOUŠEK, O. - BAUMRUK, J. Ergonomické uspořádáni a vybaveni pracovního místa. Praha: SZÚ, 1998. 23 s. ISBN 80-7071098-5.
[7] PANAGIOTOPOULOU, G., CHRISTOULAS, K., PAPANCKOLAOU, A., MANDROUKAS, K. Classroom furniture dimensions and anthropometric measures in primary school. Applied Ergonomics. Volume 35, Issue 2, March 2004, Pages 121-128.

[8] SHANNON, G. CUNNINGHAM, S. J. Impact of classroom design on interactive whiteboard use in a special needs classroom. CHINZ '09 Proceedings of the 10th International Conference NZ Chapter of the ACM's Special Interest Group on Human-Computer Interaction. ACM New York, NY, USA, 2009. ISBN 978-160558-574-1.

Lektoroval: Mgr. René Szotkowski, Ph.D.

Př́spěvek vznikl za podpory mezinárodního projektu „Diseminace nástrojů metodické podpory učitelů technických předmětů “ č. 7AMB12SK106.

Jiř́i Dostál, PaedDr. PhDr. Ph.D., Pedagogická fakulta UP, Žižkovo nám. 5, 77140 Olomouc, ČR, tel.: 00420585635818 , fax 00420585231400 , e-mail: j.dostal@upol.cz Zuzana Kopečková, Mgr., Pedagogická fakulta UP, Žižkovo nám. 5, 77140 Olomouc, $\check{C} R$, e-mail: kopeckovazuzana@seznam.cz 